\title{
Pemanfaatan ampas tahu dan eceng gondok sebagai pakan lele pada kolam terpal di Dusun I Desa Lubuk Siam Kecamatan Siak Hulu Kabupaten Kampar, Riau
}

\author{
Efawani*, Tengku Dahril, Ridwan Manda Putra, Deni Efizon, Yuliati, \& Rivco Hastwoyundra \\ Fakultas Perikanan dan Kelautan, Universitas Riau \\ * efawaniis@gmail.com
}

\begin{abstract}
Abstrak. Kegiatan pengabdian kepada masyarakat ini tentang Pemanfaatan Ampas Tahu dan Eceng gondok Sebagai Pakan Lele pada Kolam Terpal yang telah dilakukan di Dusun I Desa Lubuk Siam Kecamatan Siak Hulu Kabupaten Kampar, Riau dalam bentuk kegiatan penyuluhan dan pelatihan. Tujuan dari kegiatan ini adalah untuk memberikan pengetahuan dan penerapan teknik pembuatan pakan lele dari ampas tahu dan eceng gondok yang difermentasi dengan EM4 untuk budidaya ikan lele pada kolam terpal. Pada pelaksanaan kegiatan penyuluhan menggunakan metode ceramah, diskusi, dan demonstrasi. Sasaran dari penyuluhan ini adalah petani ikan/mitra dan masyarakat Dusun I Desa Lubuk Siam. Hasil dan ketercapaian sasaran mendapatkan solusi mengatasi permasalahan biaya pakan lele dan lamanya jangka waktu produksi/panen ( \pm 6 bulan) dalam usaha budidaya yang dilakukannya menjadi $\pm 3,5$ meminimalisir biaya pakan dari Rp.17.000-Rp.20.000/kg menjadi Rp.3.000-Rp.5.000/kg, jadi menghemat biaya pakan ikan sebesar 50-60\%. Kegiatan Pengabdian ini mendapat respon positif dari Kepala Desa dan perangkat desa, serta masyarakat Desa Lubuk Siam. Upaya pemberdayaan masyarakat Desa Lubuk Siam ini, dapat dilihat bahwa mitra sudah berhasil membuat pakan sendiri, menambah pendapatan mitra untuk kolam ukuran $10 \mathrm{~m}$ x 16 m dengan padat tebarnya 25.000-30.000 ekor sebesar Rp.3.000.000-Rp.4.000.000/bulan dan meningkatkan gizi keluarga.
\end{abstract}

Kata kunci: ampas tahu; budidaya ikan lele; eceng gondok; kolam terpal

\begin{abstract}
The activities of this community about utilization of tofu dregs and water hyacinth as catfish feed in tarpaulin ponds that have been done in Lubuk Siam Village, Siak Hulu Sub-District, Kampar Regency, Riau, the form of public awareness and training. The purpose of this activity is to providing knowledge and application of techniques about making feed catfish from the tofu dregs and water hyacinth are fermented with the EM4 for catfish farming in tarpaulin ponds. On the implementation of this extension and training activities using methods lectures, discussions and demonstrations. The target fish farmers/partners and the community on Hamlet I in Lubuk Siam Village. Results and achievement of targets have provided solutions to overcome the problem of catfish feed costs and the length of the production/harvest period ( \pm 6 months) in the cultivation business it does to \pm 3.5 months by minimizing feed costs from Rp.17,000-Rp.20,000/kg to Rp.3,000-Rp.5,000/kg, so you can save on fish feed costs by 50-60\%. This Community Service activity received a positive response from the Village Head and village officials and the people of Lubuk Siam Village. Efforts to empower the community of Lubuk Siam Village, it can be seen that the partners have succeeded in making their own feed, adding to the partner's income for a pool measuring $10 \mathrm{~m} \times 16 \mathrm{~m}$ with a dense thickness of 25,000-30,000 head of Rp.3,000,000-Rp.4,000,000/month and can improve family nutrition.
\end{abstract}

Keywords: catfish feed; tarpaulin pond; tofu dregs; water hyacinth

To cite this article: Efawani, T. Dahril, R. M. Putra, D. Efizon, Yuliati, \& R. Hastwoyundra. 2019. Pemanfaatan ampas tahu dan eceng gondok sebagai pakan lele pada kolam terpal di Dusun I Desa Lubuk Siam Kecamatan Siak Hulu Kabupaten Kampar, Riau. Unri Conference Series: Community Engagement 1: 486-492 https://doi.org/10.31258/unricsce.1.486-492

(C) 2019 Authors

Peer-review under responsibility of the organizing committee of Seminar Nasional Pemberdayaan Masyarakat 2019 


\section{PENDAHULUAN}

Desa Lubuk Siam merupakan salah satu desa di Kecamatan Siak Hulu Kabupaten Kampar. Desa ini merupakan desa yang mempunyai potensi dibidang perikanan, yakni Danau Lubuk Siam, tetapi belum dimanfaatkan sepenuhnya sumber daya perairan, seperti ikan dan tumbuhan air. Masyarakat Desa Lubuk Siam mempunyai mata pencaharian sebagai petani ikan, berkebun karet dan sawit, berternak, berdagang, dan pegawai negeri sipil. Desa Lubuk Siam ini terdiri dari empat dusun, salah satunya adalah Dusun I.

Dusun I Desa Lubuk Siam ini mempunyai potensi perikanan yakni sumber daya perairan, seperti ikan secara intensif ditangkap terus menerus dan eceng gondok yang telah menjadi gulma, karena keberadaan sumber daya tumbuhan eceng gondok sangat cepat pertumbuhannya di Danau Lubuk Siam ini. Keberadaan eceng gondok di perairan apabila melimpah (blooming) sehingga dapat menutupi permukaan perairan dan berdampak negatif terhadap ekosistem perairan dan bersifat gulma di perairan. Selain itu limbah pabrik tahu apabila dibuang langsung ke perairan dapat mengakibatkan kadar amoniak meningkat dan menurunkan kualitas perairan. Oleh karena itu tumbuhan air dan ampas tahu ini dapat dijadikan sebagai formula bahan baku pakan organik untuk usaha budidaya ikan lele, sehingga dapat meminimalisir dari biaya produksi selama pemeliharaan ikan lele sampai panen. Efawani (2014) menyatakan bahwa berdasarkan pengamatan dan praktek langsung di lapangan ternyata bisa dimanfaatkan bahan organik berupa ampas tahu dan eceng gondok sebagai pakan alternatif untuk ikan lele, sehingga tidak membutuhkan modal yang terlalu banyak untuk pembelian pakan pelet, karena ampas tahu dan eceng gondok bisa dengan mudah ditemukan. Kalau dijual pun bahan tersebut relatif lebih murah dibandingkan dengan harga pelet. Menurut Rustadi (2004) bahwa ada 3 (tiga) alasan mengapa budidaya ikan memerlukan pakan: 1) Kebanyakan luas kolam adalah dibuat sempit 300-400 $\mathrm{m}^{2}$ bahkan kurang, maka untuk memperoleh produksi yang tinggi ditebari benih yang padat sehingga diperlukan pakan. 2) Air atau kolam yang digunakan tidak subur sehingga tidak tersedia makanan alami. 3) Usaha budidaya ikan bisa merupakan usaha komersial skala besar sehingga untuk mendapatkan keuntungan diperlukan produktifitas tinggi dan waktu yang tepat.

Tumbuhan eceng gondok ini lebih berarti guna apabila masyarakat dusun ini dapat memanfaatkannya sebagai pakan organik. Akan tetapi upaya untuk pengembangan potensi dan sumber daya perairan ini, masyarakat setempat belum dapat memanfaatkannya secara optimal, seperti gulma di perairan (eceng gondok) dan limbah dari pabrik tahu dapat dijadikan sebagai pakan alternatif untuk budidaya ikan. Minat masyarakat untuk melestarikan sumber daya perikanan dengan budidaya ikan di kolam terpal belum banyak, sehingga untuk memulai membuka usaha budidaya ikan, khususnya ikan lele, disebabkan pengetahuan yang masih rendah dan khususnya dana untuk pembelian pakan yang sangat mahal. Selain dana pembelian pakan untuk usaha budidaya ikan ini sangat besar biayanya, sehingga berasumsi usaha budidaya ikan ini hanya merugi saja. Pola pikir masyarakat seperti inilah sehingga masyarakat setempat kurang berminat untuk membuka usaha budidaya ikan lele ini. Selain itu juga tidak ada upaya untuk meningkatkan gizi, khususnya dari sumber daya hayati perairan, seperti ikan lele, dimana ikan lele ini mengandung protein yang cukup tinggi untuk perkembangan otak anak, khususnya balita sebagai generasi penerus bangsa. Untuk mengatasi hal tersebut dapat diupayakan dengan membuat pakan alternatif yakni pakan organik dari tumbuhan air, yakni tumbuhan eceng gondok dan limbah dari pabrik tahu seperti ampas tahu. Kenaikan produksi budidaya ikan dalam kolam air tawar pun cukup pesat, yaitu berkisar $11 \%$ setiap tahunnya. Hal ini menunjukkan adanya semangat yang tinggi di masyarakat untuk mengembangkan usaha budidaya ikan air tawar. Tentunya pertumbuhan produksi ini mengacu pada permintaan pasar yang terus meningkat. Produksi budidaya ikan air tawar dalam kolam didominasi oleh ikan mas, lele, patin, nila, dan gurame. Lima jenis ikan tersebut menyumbang lebih dari $80 \%$ dari total produksi. Secara umum komersialisasi budidaya ikan air tawar dibagi dua segmen, yaitu pembibitan dan pembesaran. Budidaya pembibitan bertujuan untuk menghasilkan bibit bagi para peternak ikan. Sedangkan budidaya pembesaran bertujuan untuk menghasilkan ikan siap konsumsi (Alam Tani, 2013).

Usaha budidaya ikan yang lebih menjanjikan yakni budidaya ikan lele, karena ikan lele ini bernilai ekonomis dengan harga Rp. 20.000 - Rp. $25.000 / \mathrm{kg}$. Selain rasanya lezat sesuai dengan selera masyarakat dan juga cukup menjanjikan peluang bisnis usaha restoran dan pecel lele sehingga berpotensi untuk dibudidayakan. Selain itu pengembangan usaha budidaya lele dapat memanfaatkan halaman pekarangan rumah yang kosong yang pemeliharaannya di kolam terpal ataupun kolam tanah sehingga dapat dikontrol setiap saat. Usaha budidaya ikan lele di kolam terpal ini dapat meningkatkan gizi protein keluarga dan perekonomia desa serta keluarga khususnya. 


\section{METODE PENERAPAN}

Pada pelaksanaan penyuluhan ini digunakan: metode ceramah, diskusi dan demonstrasi. Penyajian materi penyuluhan di dalam kelas digunakan metode ceramah dan diskusi. Sedangkan di luar kelas digunakan metode demonstrasi.

Materi yang akan diberikan pada kegiatan ini adalah:

1. Memberikan dan mengajarkan petunjuk teknis pembuatan kolam terpal, bagaimana pengelolaan air dan perawatan ikan lele.

2. Memberikan dan mengajarkan petunjuk teknis pembuatan pakan organik ikan lele dari ampas tahu dan tumbuhan eceng gondok yang difermentasi dengan EM4 dari kajian ekonomi efektifitasnya dalam penekanan biaya produksi.

3. Penerapan pakan ikan alternatif produksi sendiri/kelompok, untuk menurunkan ketergantungan terhadap peletikan konvensional dari pabrik yang harganya relatif mahal, sehingga dalam kajian ekonominya dapat menekan biaya produksi/pemeliharaan ikan lele.

4. Evaluasi dan monitoring seberapa besar pemberdayaan dari nilai ekonomi untuk melakukan perbaikan dan modifikasi dari penerapan teknologi fermentasi dan pembuatan pakan ikan lele tersebut, agar diperoleh hasil yang lebih optimum dan seberapa besar dapat meningkatkan pendapatan para petani lele dan masyarakat setempat menjadi indikator utama.

Materi yang disampaikan:

- Teknik Pembuatan Kolam Terpal:

- Kolam dibuat dari kayu atau bambu dan dilapisi dengan terpal.

- Kolam juga dilengkapi dengan aerator dan penyaringan air kolam.

- Penyiapan Kolam Tempat Budidaya Ikan Lele:

- Sebelum benih ikan ditebar, kolam dibersihkan/dicuci terlebih dahulu.

- Kolam diisi dengan air setinggi 30-40 cm, kemudian diberi EM4 sebanyak $100 \mathrm{ml} / \mathrm{m}^{3}$

- Dibiarkan kolam tersinari matahari selama satu minggu agar plankton tumbuh sebagai pakan alami

- Setelah satu minggu benih ikan lele siap ditebar.

- Kekeruhan air kolam dari sisa-sisa pakan dan kotoran ikan diatasi dengan pemberian EM4 untuk menjaga kualitas air dengan baik.

Teknik Pembuatan Pakan Organik Ikan Lele dari Ampas Tahu dan Tumbuhan Eceng Gondok:

\section{Pembuatan pakan dari fermentasi ampas tahu}

Sebelumnya dipersiapkan bahan-bahan sebagai berikut:

- Ampas tahu $5 \mathrm{~kg}$.

- Dedak halus $5 \mathrm{~kg}$.

- Tepung ikan $1 \mathrm{~kg}$.

- Tetes tebu/molases 1 liter.

- Probiotik (EM4 perikanan): $200 \mathrm{ml}$.

- Ragi tempe $2 \mathrm{sdm}$.

Setelah seluruh bahan dicampur dan diaduk rata, kemudian dimasukkan ke dalam drum/ember/kantong plastik yang diberi lobang udara dengan menggunakan selang untuk mengalirkan gas/udara yang ujungnya ditutup plastik atau bekas gelas air mineral tetapi jangan terlalu tertutup rapat (sebagian terbuka untuk keluar masuknya oksigen). Kemudian disimpan dan dibiarkan selama $+/-5$ hari agar terjadi proses fermentasi secara alami.

Setelah difermentasi 5 hari pakan lele organik sudah bisa dimanfaatkan dengan ketentuan sebagai berikut:

- Bisa diberikan langsung ke lele dengan cara dikepalkan sehingga lele bisa mengkonsumsi secara langsung.

- Disarankan diberikan ke lele yang umurnya di atas 1 bulan dari penebaran ukuran benih 5-7/7 - 9, sebelumnya bisa diberikan dari hasil fermentasi dan pakan alami pupuk kandang.

- Pemberiannya jangan bersamaan dengan pemberian pelet ikan.

- Persentase pemberian $5 \%$ dari biomas ikan (1,5 - 2 kali jumlah pemberian pakan pelet). 
- Frekuensi pemberian pakan lele organik dari ampas tahu ini bisa 2-3 kali sehari diberikan pada pagi/siang hari.

\section{Pembuatan pakan dari eceng gondok}

Eceng gondok yang akan digunakan sebagai suplemen nabati diambil daun dan pelepahnya $5 \mathrm{~cm}$ dari bawah daun. Selanjutnya dipotong-potong dan dikeringkan di bawah sinar matahari. Setelah kering digiling untuk dijadikan tepung. Selanjutnya dilakukan penambahan dengan tepung ikan sebagai suplemen hewani (dua komponen tersebut merupakan bangsal B). Kemudian bangsal B tersebut ditambahkan dengan bangsal A, dimana bangsal A ini diambil dari dedak halus dan tepung tapioka atau bisa juga digunakan tepung terigu. Selanjutnya ketiga komponen dari yaitu bangsal B dan bangsal A ditambahkan tetes tebu, ragi tempe, dan EM4-perikanan, lalu diaduk sehingga semua adonannya menjadi homogen. Kemudian disimpan dan dibiarkan selama 7 hari agar terjadi proses fermentasi secara alami, dan pakan organik ikan lele siap diberikan.

\section{HASIL DAN KETERCAPAIAN SASARAN}

Pelaksanaan penyuluhan dan pelatihan tentang pakan organik ikan lele dari ampas tahu dan eceng gondok selama kurang lebih 1 (satu) bulan yang telah dilaksanakan di Desa Lubuk Siam Kecamatan Siak Hulu Kabupaten Kampar dengan peserta sebanyak 20 - 25 orang yang terdiri dari masyarakat setempat yang ratarata pekerjaannya sebagai petani sawit dan karet, pegawai, buruh, petani ikan dan ibu rumah tangga yang telah berjalan dengan baik, lancar dan tertib. Pelaksanaan penyuluhan ini dibantu oleh mahasiswa Kukerta Terintegrasi UNRI 2019 berjumlah 11 orang.

Peserta mempunyai semangat yang tinggi dan antusias untuk mengikuti penyuluhan ini, hal ini terlihat cukup banyak peserta yang hadir pada penyuluhan ini. Dalam pemberian materi, disampaikan dengan bahasa yang mudah dimengerti dan dipahami, sehingga peserta dengan mudah menangkap dan mencerna materi yang disampaikan. Ini ditunjukkan dengan banyaknya pertanyaan sewaktu mengikuti penyampaian materi dan pelatihan di lapangan. Hal ini juga didukung oleh permasalahan yang dihadapi petani/pembudidaya ikan lele dari mahalnya biaya produksi yakni pakan konvensional (pelet), dimana kolam yang berukuran $10 \mathrm{~m}$ x $16 \mathrm{~m}$ dengan jumlah ikan lele 25.000 - 30.000 ekor memerlukan biaya pakan/pelet konvensional sebesar Rp. 10.000.000 - Rp. 12.000.000 sampai panen.

Anggota kelompok petani/pembudidaya ikan berpartisipasi aktif dalam mengikuti kegiatan ini, karena mereka dalam usaha budidaya ikan lele yang dilakukannya di kolam terpal tidak menghasilkan produksi ikan yang optimal. Bahkan dalam usahanya itu, belum sampai panen sudah banyak ikannya yang mati. Jadi dalam usaha budidaya yang mereka lakukan itu sangat merugi. Oleh karena itu dalam pelaksanaan penyuluhan dan pelatihan ini, mereka memperhatikan dan melaksanakan dengan sungguh-sungguh sesuai dengan acuan kerja dalam lembaran copyan yang diberikan.

Sebelum kegiatan pelatihan pembuatan pakan organik lele fermentasi, beberapa bahan dan peralatan telah disiapkan untuk kelancaran kegiatan. Bahan-bahan yang digunakan disiapkan dan dikerjakan, seperti: menyiapkan bahan baku pakan dari ampas tahu yang akan difermentasikan, perendaman, penjemuran, serta pemblenderan daun eceng gondok menjadi tepung yang akan difermentasikan dengan menggunakan probiotik/EM4 (Effective Microorganism 4) perikanan. Prinsip fermentasi adalah mengaktifkan kegiatan mikroba tertentu dengan tujuan mengubah sifat bahan agar dihasilkan sesuatu yang bermanfaat. Selain itu pada proses fermentasi juga terjadi pemecahan komponen yang komplek menjadi zat-zat yang lebih sederhana, serta pemecahan bahan-bahan yang tidak dapat dicerna, seperti: selulosa, hemiselulosa menjadi gula sederhana sehingga mudah dicerna oleh ternak (Widayati dan Widyalestari, 1996). Menurut Nurhajati et al. (1996) dalam Susanti (2006), kelompok mikrobia yang mempunyai peranan penting dalam proses fermentasi adalah ragi (khamir), jamur (kapang), bakteri, dan beberapa spesies Actinomycetes. Gardjito (1992) menyatakan bahwa umumnya mikroba mati pada suhu tinggi, sehingga pada proses fermentasi suhunya dijaga jangan sampai terlalu tinggi. Suhu tinggi dapat merusak enzim yang dihasilkan mikroba, namun pada suhu rendah aktifitas mikroba terhambat. Rahayu dan Soedarmaji (1989) menyatakan bahwa faktor-faktor yang perlu diperhatikan dalam proses fermentasi antara lain: air, suhu, $\mathrm{pH}$, fermentator, susunan bahan dasarnya, dan adanya zat yang bersifat pendukung. Sedangkan Iksan (2002) menyatakan bahwa kandungan air pada bahan merupakan faktor yang sangat berpengaruh pada proses fermentasi. Kandungan air yang optimal pada bahan dalam keadaan segar berkisar 60\% - 70\% atau 65\%. Menurut Judoamidjoyo (1990) bahwa hal yang paling penting dalam proses fermentasi adalah bahan baku dan bahan pembantu yang disebut substrat atau medium yang fungsinya selain sebagai bahan pembentuk sel dan produk metabolisme, juga sebagai sumber energi. 
Pakan organik dari ampas tahu dan eceng gondok yang dilakukan, mengingat setiap tahapan pekerjaan memerlukan waktu pendiaman yang cukup lama, seperti untuk membuat pakan fermentasi perlu dilakukan pemeraman untuk pakan dari ampas tahu \pm 5 hari dan eceng gondok \pm 7 hari. Dengan mekanisme pelaksanaan pembuatan pakan dari ampas tahu dan eceng gondok ini dari penyiapan bahan dan alat, pengolahan bahan, dan fermentasi dari bahan tersebut berjalan dengan lancar. Sedangkan hasil dari proses fermentasi ampas tahu dan eceng gondok tadi selama waktu fermentasi 5 - 7 hari dapat diberikan langsung ke kolam terpal ikan lele. Menurut Efawani (2017) bahwa berdasarkan hasil penelitian, eceng gondok dapat digunakan dalam pembuatan tepung eceng gondok yang difermentasi untuk bahan baku formulasi pakan benih ikan lele. Penggunaan tepung eceng gondok sampai dengan tingkat $30 \%$ tidak memberikan perbedaan yang nyata antar perlakuan terhadap pertumbuhan dan efisiensi pemberian pakan pada benih ikan lele

Berhasilnya kegiatan penyuluhan dan pelatihan ini tidak luput dari bantuan mahasiswa Kukerta Terintegrasi UNRI 2019 dalam mengkoordinasi terlaksananya penyuluhan dan pelatihan ini, seperti: mengkonfirmasikan waktu pelaksanaannya dilakukan dengan Kepala Desa dan perangkat desa lainnya, serta mengedarkan undangan kepada masyarakat Desa Lubuk Siam. Kegiatan pelatihan berjalan dengan lancar, karena sesungguhnya membuat pakan organik ikan lele dari ampas tahu dan eceng gondok yang difermentasi, sangat sederhana, tidak ada permasalahan dari peserta untuk membuatnya. Ini terbukti bahwa target penyampaian tercapai kepada peserta, karena mereka semuanya antusias mengikuti dalam penyuluhan dan pelatihan banyaknya pertanyaan yang muncul dalam penyampaian materi tersebut.

Semua peserta sudah memiliki keterampilan untuk membuat pakan organik yang difermentasi dari ampas tahu dan eceng gondok. Hal ini dapat dilihat dari hasil fermentasi yang telah dibuat oleh peserta langsung diberikan dan dimakan oleh ikan di dalam kolam. Tingkat kesukaan ikan lele di kolam terpal ini sangat tinggi dengan pemberian pakan fermentasi dengan EM4 dari ampas tahu dan eceng gondok. Pakan yang ditaburkan di atas permukaan air kolam tidak ada yang tersisa. Sesuai dengan sifat dari ikan lele ini yang rakus, jadi pemberian pakannya dilakukan dengan frekuensi waktu yang lebih banyak dengan porsi yang cukup.

Pakan organik ikan lele yang difermentasi dari ampas tahu dan eceng gondok dibuat dengan bahan-bahan limbah pertanian pabrik tahu, dan tumbuhan air yang bersifat gulma di perairan, seperti: ampas tahu, dedak halus dan eceng gondok. Semua bahan ini tidak sulit untuk mendapatkannya, karena limbah-limbah pabrik tahu dan gulma dari tumbuhan eceng gondok dengan mudah mendapatkannya di lingkungan sekitar dan tidak memerlukan biaya tinggi dan dapat dimanfaatkan dan bernilai guna. Dengan pemanfaatan pakan dengan ampas tahu dan eceng gondok yang difermentasi dengan EM4 ini dapat menekan atau meminimalisir biaya pakan dibandingkan dengan pakan konvensional, yakni dengan harga Rp. 17.000 - Rp. 20.000/kg, sedangkan dengan ampas tahu dan eceng gondok menghemat biaya Rp. 3.000 - Rp. $5.000 / \mathrm{kg}$, sehingga besarnya pengurangan biaya produksi sebesar $50-60 \%$.

Pakan lele fermentasi yang dibuat memiliki bau yang berbeda dengan pakan konvensional dijual dipasaran yang lebih berbau ikan kering. Produk yang dibuat juga lebih ringan daripada pakan konvensional yang dijual. Produk yang dibuat juga disukai oleh ikan lele. Pakan fermentasi ini cukup baik sebagai makanan ikan lele, mengingat tingginya harga pakan konvensional lele dipasaran.

Tingkat keberhasilan dalam pemecahan masalah yang biasa dihadapi oleh para petani ikan mengenai pakan sudah dapat terpecahkan dengan membuat pakan alternatif untuk usaha budidaya ikan lele di Desa Lubuk Siam ini, dengan pertumbuhan ikan lele yan dipelihara di kolam terpal dari ukuran benih $3-5 \mathrm{~cm}$ dengan bobot 3 $4 \mathrm{~g}$, dalam waktu 1,5 bulan sudah mencapai ukuran $13-15 \mathrm{~cm}$ dengan bobot 9 - $10 \mathrm{~g}$. Menurut Asmawi (1986) bahwa faktor makanan mempunyai peranan yang sangat penting dalam pertumbuhan individu. Untuk merangsang pertumbuhan yang optimal, diperlukan jumlah dan mutu makanan yang tersedia dalam keadaan cukup serta sesuai dengan kondisi perairan. Pemberian makanan yang bergizi adalah untuk memperoleh pertambahan daging yang sebanyak-banyaknya dalam waktu sesingkat mungkin. Selanjutnya Ichwan (1997) menyatakan bahwa kualitas dan kuantitas makanan ikan juga tergantung pada ukuran makan yang cocok untuk mulut ikan.

Dampak dari kegiatan penyuluhan dan pelatihan dalam memberikan informasi dan pengetahuan untuk membuka cakrawala berfikir masyarakat, khususnya petani ikan/mitra Desa Lubuk Siam ini dari permasalahan yang ada di desa tersebut mendapat tanggapan positif dan perhatian dari Kepala Desa dan perangkat Desa Lubuk Siam, tergantung keberlanjutan pelaksanaan dalam upaya pemberdayaan masyarakat di Desa Lubuk Siam ini. Upaya pemberdayaan masyarakat di desa ini dapat meningkatkan gizi masyarakat, perekonomian keluarga, masyarakat khususnya petani ikan/mitra dan kas Desa Lubuk Siam ini. 


\section{KESIMPULAN DAN SARAN}

\section{Kesimpulan}

Setelah dilakukan penyuluhan dan pelatihan pemanfaatan ampas tahu dan eceng gondok sebagai pakan organik untuk budidaya ikan lele pada kolam terpal di Desa Lubuk Siam Kecamatan Siak Hulu Kabupaten Kampar ini, khususnya petani ikan/mitra dan masyarakat yang berminat, sudah ada salah satu solusi upaya mengatasi permasalahan biaya mengenai pakan ikan lele dan lamanya jangka waktu produksi/panen ( \pm 6 bulan) dalam usaha budidaya yang dilakukannya menjadi $\pm 3,5$ bulan dengan meminimalisir biaya pakan dari Rp.17.000 Rp. $20.000 / \mathrm{kg}$ menjadi Rp.3.000-Rp.5.000/kg, jadi dapat menghemat biaya produksi sebesar $50-60 \%$ Pelaksanaan kegiatan Pengabdian Kepada Masyarakat ini mendapat respon yang positif dari Kepala Desa dan aparat desa serta masyarakat Desa Lubuk Siam. Upaya pemberdayaan masyarakat Desa Lubuk Siam ini, tingkat keberhasilannya dapat dilihat bahwa mitra sudah berhasil membuat pakan sendiri, menambah pendapatan mitra untuk kolam ukuran $10 \mathrm{~m}$ x $16 \mathrm{~m}$ dengan padat tebarnya $25.000-30.000$ ekor sebesar Rp. 3.000.000 - Rp. 4.000.000/bulan dan dapat meningkatkan gizi keluarga.

\section{Saran}

Dengan bekal wawasan dan keterampilan yang telah diberikan, disarankan mitra bisa terus mengembangkan pemanfaatan sumberdaya alam baik dari hewan dan tumbuhan, dimana dapat dikembangkan formula pakan yang benar-benar berbasis bahan-bahan lokal yang banyak tersedia di lingkungan sekitar, seperti: kotoran hewan ternak (ayam, kambing, dan lain-lain), tumbuhan air (azolla, kiambang, kiapu, dan lain-lain), sehingga biaya pakan ikan dapat ditekan seminimal mungkin dengan produksi yang tinggi.

\section{UCAPAN TERIMAKASIH}

Ucapan terima kasih disampaikan kepada LPPM Universitas Riau yang telah membantu pendanaan dari sumber dana DIPA UNRI Tahun 2019 dalam kegiatan Pengabdian Kepada Masyarakat sampai selesainya penulisan laporan pengabdian ini.

\section{DAFTAR PUSTAKA}

Alam Tani Panduan Usaha Tani. 2013. Potensi Usaha Budidaya Ikan Air Tawar. http://www.alamtani.com/ikan-air-tawar.html Diakses pada 31 Juli 2013.

Asmawi, S. 1986. Pemeliharaan Ikan dalam Keramba. Jakarta: PT Gramedia.

Efawani, T. Dahril, R. M. Putra, Budijono, \& R. Janatul. 2017. Penggunaan Eceng Gondok (Eichhornia crassipes) dalam Pakan dan Implikasinya pada Ikan Lele. Pekanbaru: LPPM Universitas Riau.

Efawani, Yuliati, Budidjono, \& Dahlia. 2014. Penyuluhan Pakan Organik Ikan Lele dari Kotoran Sapi dan Ampas Tahu di Desa Buana Bhakti Kecamatan Kerinci Kanan Kabupaten Siak. Pekanbaru: LPPM Universitas Riau.

Effendie, M. I. 2006. Metode Biologi Perikanan. Bogor: Yayasan Dwi Sri.

Gardjito, M., S. Naruki, A. Murdiati, \& Sardjono. 1992. Ilmu Pangan, Pengantar Ilmu Pangan, Nutrisi dan Mikrobiologi. Edisi Kedua. Yogyakarta: Gadjah Mada University Press.

Ichwan, M. 1997. Hubungan Makanan yang Dimakan Ikan Motan dengan Lingkungan Alaminya di Danau Baru Desa Buluh Cina Kecamatan Siak Hulu Kabupaten Kampar Provinsi Riau. Skripsi. Fakultas Perikanan Universitas Riau, Pekanbaru.

Iksan, M. 2002. Teknik Fermentasi Hijauan Makanan Ternak. Pikiran Rakyat Cyber Media. http://pikiran-rakyat.com Diakses pada 27 September 2010.

Judoamidjoyo, M. A. A., Darwis, \& E. G. Sa’id. 1990. Teknologi Fermentasi. Bogor: PAU Bioteknologi Institut Pertanian Bogor.

Rahayu, K. K., \& Soedarmaji. 1989. Mikrobiologi Pangan. PAU Pangan dan Gizi. Yogyakarta: Universitas Gadjah Mada.

Rustadi. 2004. Buku Petunjuk Praktikum Mata Kuliah Budidaya Perairan Tawar. Proyek Peningkatan Universitas Gadjah Mada. Kegiatan Peningkatan Kualitas Program Studi Budidaya Perikanan Jurusan Perikanan Fakultas Pertanian Universitas Gadjah Mada. Yogyakarta. 
Susanti, K. 2006. Kandungan Serat Kasar dan Protein Kasar Tongkol Jagung Hasil Proses Fermentasi dengan Probiotik Alami. Skripsi. Fakultas Kedokteran Hewan Universitas Airlangga. Surabaya.

Widayati, E. dan Y. Widalestari. 1996. Limbah untuk Pakan Ternak. Jakarta: Trubus Agrisarana. 